\section{THU0129 ASSESSMENT OF LONELINESS IN PATIENTS WITH INFLAMMATORY ARTHRITIS}

Hakan Emmungil ${ }^{1}$, Ufuk İlgen ${ }^{1}$, Sezin Turan ${ }^{1}$, Özge Kllıç2. ${ }^{1}$ Trakya University, Edirne, Turkey, ${ }^{2}$ Koç University Hospital, Psychiatry, İstanbul, Turkey

Background: Rheumatic disease and psychosocial status have bi-directional impacts on each other. Loneliness, as a component of psychosocial status, may be interrelated with affect and social support and may also be influenced by the disease itself in patients with inflammatory arthritis ${ }^{1}$. Objectives: The aim of this study is to document loneliness and associated factors in patients with inflammatory arthritis. Effects of demographic and disease-related factors, functional status, affect, and social support on loneliness, and loneliness on functional status will be evaluated.

Methods: Consecutive patients with rheumatoid arthritis(RA), ankylosing spondylitis(AS), and psoriatic arthritis(PsA), meeting ACR, ASAS, and CASPAR criteria, respectively, were included in the study. Demographic data and general clinical parameters(Table 1) were identified for each patient. Beck depression and Beck anxiety inventory, revised multidimentional scale of percieved social support, HAQ-DI, and UCLA loneliness scale (ULS-8), all validated in Turkish population, were used for the assessments. Nonparametric comparison (Wilcoxon-Mann-Whitney and Kruskal-Wallis) and correlation(Spearman) tests were used to evaluate associations of demographic data, clinical parameters, and depression, anxiety, social support, HAQ-DI scores with ULS-8 score. Multiple regression models were generated for significant associations.

Results: Demographic data, general clinical features, functional status, and ULS-8 scores of disease groups are summarized in Table 1. Among demographic and general clinical parameters, higher number of total drugs and lower education were associated with significantly higher ULS8 scores (data not shown). Although weak, there were significant correlations between ULS-8 and HAQ-DI, depression, anxiety, social support, and doctor global VAS scores (Table 2). Stronger correlations were observed between HAQ-DI and depression, anxiety, and patient global VAS scores (Table 2). Among demographic and general clinical parameters, only number of drugs was weakly associated with HAQ-DI score (rho $=0.18, p=0.037)$. Two multiple regression models were generated for predicting HAQ-DI and ULS-8 scores. Depression, anxiety and patient global VAS scores remained significant for predicting HAQ-DI after multiple regression with covariates ULS-8, depression, anxiety, social support, patient and doctor global VAS scores, and number of drugs used (adjusted $\left.R^{2}=0.53, p<0.001\right)$. Although significant $(p<0.001)$, only $14 \%$ of variance in ULS-8 may be jointly explainable with covariates HAQ-DI, depression, anxiety, social support, doctor global VAS scores, number of drugs used, and education status. The only independent predictor was the education status. ULS-8 score did not correlate with DAS28, CDAI, and SDAI in RA; BASDAI, BASFI, and ASDAS in AS; and number of swollen and tender joints, ESR, CRP, patient global, doctor global, pain, and fatigue VAS scores in PSA.
Abstract THU0129 -Table 1.

Table 1. Demographic data, general clinical parameters, functional status, and ULS-8 scores according to disease groups.

\begin{tabular}{|c|c|c|c|c|}
\hline & $\begin{array}{c}\text { RA } \\
(n=58)\end{array}$ & $\begin{array}{c}\text { AS } \\
(n=53)\end{array}$ & $\begin{array}{c}\text { PsA } \\
(n=30)\end{array}$ & p value \\
\hline Age, years & $\begin{array}{c}58(\mathrm{QQR} \\
12)^{\mathrm{a}, \mathrm{b}}\end{array}$ & $\begin{array}{c}42(\text { IQR } \\
14)^{\mathrm{a}}\end{array}$ & $\begin{array}{c}45(\mathrm{IQR} \\
20)^{\mathrm{b}}\end{array}$ & $<0.001$ \\
\hline Female, $\mathbf{n}(\%)$ & $41(70,7)^{\mathrm{a}}$ & $19(35,8)^{a, b}$ & $21(70)^{b}$ & $<0.001$ \\
\hline Married, $\mathbf{n}(\%)$ & $46(79,3)$ & $46(86,8)$ & $28(93,3)$ & 0.196 \\
\hline Number of children & 2 (IQR 0$)$ & 2 (IQR 1) & 2 (IQR 1) & 0.102 \\
\hline Household size & 3 (IQR 2) & 4 (IQR I) & 4 (IQR 1) & 0.057 \\
\hline Education status, $\mathbf{n}(\%)$ & & & & $0.001^{\dagger}$ \\
\hline $\begin{array}{l}\text { Primary school or } \\
\text { lower }\end{array}$ & $33(56,9)^{a}$ & $13(24,5)^{a}$ & $14(46,7)$ & \\
\hline $\begin{array}{l}\text { Secondary or high } \\
\text { school }\end{array}$ & $17(29,3)^{a}$ & $28(52,8)^{\mathrm{a}}$ & $16(53,3)$ & \\
\hline Higher education & $8(13,8)$ & $12(22,6)^{\mathrm{a}}$ & $-a^{a}$ & \\
\hline Active & $16(27,6)^{2}$ & $31(58,5)^{2}$ & $10(33,3)$ & $.003^{\dagger}$ \\
\hline $\begin{array}{l}\text { Comorbid disease } \\
\text { present*, } n(\%)\end{array}$ & $36(62,1)^{a}$ & $19(35,8)^{a}$ & $12(40)$ & $0.014^{\dagger}$ \\
\hline$r$ of drugs & $5(\mathrm{IQR} 3)^{\mathrm{a}}$ & $2(\text { IQR } 1)^{a, b}$ & $5\left(\right.$ IQR 3) ${ }^{b}$ & $<0.001^{\dagger}$ \\
\hline gears & 8 (IQR 8) & 9 (IQR 9) & 9,5 (IQR 14) & 0.555 \\
\hline $\mathrm{ESR}, \mathrm{mm} / \mathrm{h}$ & $\begin{array}{c}25(I Q R \\
26)^{\mathrm{a}}\end{array}$ & $\begin{array}{c}13(I Q R \\
15)^{\mathrm{a}}\end{array}$ & 19 (IQR 22) & $0.014^{\dagger}$ \\
\hline CRP, $\mathbf{~ m g / L ~}$ & $6($ IQR 8,8) & $\begin{array}{c}7,6 \text { (IQR } \\
9,3)\end{array}$ & 5,1 (IQR 6) & 0.396 \\
\hline bioDMA & $6(10,3)^{a, b}$ & $37(69,8)^{2}$ & $16(53,3)^{b}$ & $<0.001$ \\
\hline $\begin{array}{l}\text { Adherent to treatment, } \\
\mathrm{n}(\%)\end{array}$ & $52(89,7)$ & $47(88,7)$ & $27(90)$ & 0.978 \\
\hline HAQ-DI groups, n(\%) & & & & 0.757 \\
\hline Mild & $52(89,7)$ & $48(90,6)$ & $29(96,7)$ & \\
\hline bility & $5(8,6)$ & $5(9,4)$ & $1(3,3)$ & \\
\hline Sev & $1(1,7)$ & - & - & \\
\hline ULS-8 score s $^{t}$ & 15 (IQR 7) & 15 (IQR 5) & 14,5 (IQR 7) & 0.749 \\
\hline $\begin{array}{l}\text { Continuous variables ar } \\
\text { (IQRs). Disease group, ag } \\
\text { comorbid disese, number } \\
\text { as appropriate. and }{ }^{b} \text { de } \\
\text { (post hoc adjusted } p<0.0 \\
\text { after control for confour } \\
\text { scores suggesting higher }\end{array}$ & $n=m$ & with & $\begin{array}{l}\text { quartile } \\
\text { tus, prese }\end{array}$ & \\
\hline
\end{tabular}

Abstract THU0129 -Table 2.

Table 2. Correlations between ULS-8, HAQ-DI, depression, anxiety, social support, and patient and doctor global VAS scores

\begin{tabular}{|c|c|c|c|c|c|c|c|}
\hline & & $\begin{array}{c}\text { Beck } \\
\text { depressi } \\
\text { on score }\end{array}$ & $\begin{array}{c}\text { Beck } \\
\text { anxiet } \\
y \\
\text { score } \\
\end{array}$ & $\begin{array}{c}\text { Social } \\
\text { support } \\
\text { score }\end{array}$ & $\begin{array}{l}\text { Patient } \\
\text { global } \\
\text { VAS } \\
\text { score }\end{array}$ & $\begin{array}{c}\text { Doctor } \\
\text { global } \\
\text { VAS } \\
\text { score } \\
\end{array}$ & $\begin{array}{l}\text { HAQ-DI } \\
\text { score }\end{array}$ \\
\hline $\begin{array}{l}\text { ULS-8 } \\
\text { score }\end{array}$ & $\begin{array}{r}\text { rho } \\
\text { p } \\
\text { value }\end{array}$ & $\begin{array}{c}0.32 \\
<0.001\end{array}$ & $\begin{array}{c}0.33 \\
<0.001\end{array}$ & $\begin{array}{l}-0.22 \\
0.009\end{array}$ & $\begin{array}{c}0.1 \\
0.224\end{array}$ & $\begin{array}{c}0.16 \\
0.058\end{array}$ & $\begin{array}{c}0.27 \\
0.001\end{array}$ \\
\hline $\begin{array}{l}\text { HAQ- } \\
\text { DI } \\
\text { score }\end{array}$ & $\begin{array}{r}\text { rho } \\
\mathbf{p} \\
\text { value }\end{array}$ & $\begin{array}{c}0.53 \\
<0.001\end{array}$ & $\begin{array}{c}0.53 \\
<0.001\end{array}$ & $\begin{array}{l}-0.25 \\
0.003\end{array}$ & $\begin{array}{c}0.5 \\
<0.001\end{array}$ & $\begin{array}{c}0.28 \\
<0.001\end{array}$ & - \\
\hline
\end{tabular}

Significant correlations exist between Beck depression, Beck anxiety,

social support, and patient and doctor global VAS scores.

Conclusion: Loneliness is associated with depression, anxiety, lack of social support, and lower education but not with disease activity in patients with inflammatory arthritis. Self -report loneliness, can be a contributing factor to the disability of the inflammatory arthritis.

\section{REFERENCE:}

[1] Kool MB, et al. Loneliness in patients with rheumatic diseases: the significance of invalidation and lack of social support. J Psychol 2012;146:229 41

Acknowledgement: no

Disclosure of Interests: Hakan Emmungil Grant/research support from: Roche, novartis, msd, Consultant for: roche, novartis, Speakers bureau: roche, novartis, msd, pfizer, celltrion, abbvie, Ufuk İlgen: None declared, Sezin Turan: None declared, Özge Kılıç: None declared

DOI: 10.1136/annrheumdis-2019-eular.7548

\section{THU0130 INCIDENCE AND RISK FACTORS OF FALLING IN PATIENTS WITH RHEUMATOID ARTHRITIS}

Rym Fakhfakh, Jguirim Mahbouba, Hibatallah Mosbeh, Abir Dghaies, Grassa Rim, Olfa Jmaa, Saoussen Zrour, Ismail Bejia, Mongi Touzi, Naceur Bergaoui. CHU Fattouma Bourguiba, Rheumatology, monastir, Tunisia

Background: People with rheumatoid arthritis (RA) may be at greater risk of falling than the non-RA population [1]. This increased falls risk may be due to RA disease-related impairments including pain, deformity and decreased muscle strength, as well as reduced functioning such as altered gait and a decline in postural stability. 
Objectives: The aim of this study was to evaluate the prevalence of falls and its association with clinical data, disease-related outcomes and physical performance tests.

Methods: Cross-sectional study including patients with RA, followed in the Rheumatology Department over a period of 1 month in 2018. The following parameters were evaluated: clinical aspects; fall occurrence in the previous 12 months; pain on a visual analogue scale (VAS); RA disease Activity Score 28 (DAS28)/erythrocyte sedimentation rate (ESR); Functional capacity assessed by the Health Assessment Questionnaire (HAQ); anxiety and depression by the Hospital Anxiety and Depression Scale (HADS) and Physical performance, assessed by 3 tests, the Timed Up and Go (TUG), one leg standing balance (OST) and sternal nudge test (SNT).

Results: Forty-eight patients were enrolled, the average age was $55.8 \pm$ 13.9 and the sex ratio was 0.14 . The average disease duration was 13.49 years \pm 9.12. The average DAS28 was $4.63 \pm 1.19$ and $\mathrm{HAQ}$ was $0.77 \pm 0.88$. Falls were reported by $44.7 \%$ of patients: $27.7 \%$ had one fall and $17 \%$ had $\geq 2$ falls. Patients had a fractures history in $10.9 \%$ of cases and dislocations in $6.5 \%$ of cases. The HAQ $(p=0.04)$ and $c$ reactive protein $(p=0.01)$ was associated with fall history; the other parameters (Gender, number of medications, age, disease activity and physical tests) showed no associations with history of falls. Physical performance was decreased to: $58.4 \%$ for TUG test, $61.7 \%$ for OST and $36.2 \%$ for SNT. The worst performance in physical tests (TUG, OST and SNT) was associated with older age, higher erythrocyte sedimentation rate, higher $\mathrm{HAQ}$, and increased DAS28 $(\mathrm{p}<0.05)$. In addition, hips and especially knees involvement was significantly associated with TUG $(p=0.03)$ and OST test $(p=0.003)$. TUG test was significantly associated with depression $(p=0.04)$. The OST test was associated with higher disease duration $(p=0.004)$, VAS $(p=0.006)$ and tender joints $(p=0.001)$. There was no association between number of falls and any of the physical performance tests.

Conclusion: It was observed that the occurrence of falls is quite common in this population. The occurrence of falls in this sample of rheumatoid arthritis patients bears no relation to disease activity or physical performance tests. But, falls were associated with functional capacity.

\section{REFERENCE:}

[1] StanmoreEK,OldhamJ,SkeltonDA,O'Neill T,PillingM,CampbellAJ,etal.Risk factors forfallsinadultswithrheumatoidarthritis:aprospectivestudy. Arthritis CareRes2013;65:1251-8.

Disclosure of Interests: None declared

DOI: 10.1136/annrheumdis-2019-eular.5038

\section{THU0131 1 EFFECT OF METABOLIC SYNDROME ON THE COURSE OF RHEUMATOID ARTHRITIS AND CARDIOVASCULAR RISK}

Svetlana Lapshina ${ }^{1,2}$, Liutsiia Feiskhanova ${ }^{1}$, Luciya Kupkenova ${ }^{1}$,

Ridiya Sharafutdinova ${ }^{1}$, Aigul Akhmetzianova ${ }^{1}{ }^{1}$ Kazan State Medical University, Kazan, Russian Federation; ${ }^{2}$ Republic Clinical Hospital, Kazan, Russian Federation

Background: Both rheumatoid arthritis (RA) and metabolic syndrome (MS) have an inflammatory component in the pathogenesis and both aggravate cardiovascular risks.

Objectives: The aim is to study the effect of MS on the course of RA and the increase in cardiovascular risk in these patients.

Methods: 100 patients (men 7\%, women 93\%) aged 21 to 81 years (average age $55 \pm 12.4$ ) with reliable RA were examined. High activity in DAS28 scale was observed in $68 \%$, moderate - in $30 \%$, low - in $2 \%$, rheumatoid factor (RF) positivity - in $88 \%$, ACCP - $81 \%$. Disease-modifying antirheumatic drugs received $78 \%$, glucocorticosteroids $60 \%$ of patients. Arterial hypertension $(\mathrm{AH})$ was present in $45 \%$ of patients. MS according to NCEP/ATPIII criteria was identified in 59 patients, according to its presence, patients were divided into 2 groups (MS+ and MS-). Patients were examined in standard laboratory tests, all of them had echocardiogram.

Results: In the presence of MS, RA activity was significantly higher (DAS28 4.2 \pm 0.5 ) compared with patients without it (DAS28 $3.5 \pm 0.6$ ) most of all because of pain syndrome $(p<0.01)$. A correlation was observed between the presence of MS and pain on a visual analogue scale and the number of painful joints $(p<0.05)$. However, there was no significant difference according to the level of the ESR, CRP, the presence of the $\mathrm{RF}$, the X-ray stage of RA. There were no differences in the range of received therapy, but the dose of prednisone was higher in the MS+ group $(7.8 \pm 3.5$ vs $6.4 \pm 3.69, \mathrm{p}<0.05)$

Systolic blood pressure (BP) was higher in the MS+ group (128.3 \pm 17.3$)$ vs MS- (119.3 \pm 15.9$)$. The level of BP correlated $(p<0.05)$ with the severity of pain. The verified $\mathrm{AH}$ was present in $42(71.2 \%)$ patients of the MS+ group (1 stage -2, 2 stage $-24,3$ stage -16 patients) and in 3 $(7.3 \%)$ patients of the MS- group (1 stage in 1 patient, 2 stages in 2 patients). The cholesterol level was higher in the MS+ group $5.1 \pm 1.1$ compared with the MS- group 4.6 $\pm 0.6(p<0.01)$. There was observed a persistent tendency $(p<0.01)$ in increasing of the mass index of the left ventricle myocardium according to echocardiogram. In patients with $\mathrm{MS}+$ hypertrophy of the left ventricular myocardium was detected according to echocardiogram even with a normal level of BP

Conclusion: The presence of MS in patients with RA is associated with a higher activity of RA most of all because of pain syndrome. At the same time, pain syndrome correlates with the level of blood pressure. The combination of MS and RA leads to an increase of cardiovascular risk factors: cholesterol level and myocardial hypertrophy, which causes the need of using the echocardiography for this group of patients.

\section{REFERENCE:}

[1] rheumatoid arthritis, metabolic syndrome.

Disclosure of Interests: None declared

DOI: 10.1136/annrheumdis-2019-eular.7822

\section{THU0132 EVALUATION OF CARDIOVASCULAR RISK FACTORS IN PATIENTS WITH RHEUMATOID ARTHRITIS TREATED WITH BIOLOGICAL AGENTS: 3-MONTH FOLLOW-UP}

Giorgos Papamichail ${ }^{1}$, Theodora Markatseli ${ }^{2}$, Athanasios Georgiadis ${ }^{2}$, Vasileios Xydis ${ }^{3}$, Haralampos Milionis ${ }^{1}$, Alexandros Drosos ${ }^{2}$, Paraskevi Voulgari ${ }^{2}$ ${ }^{1}$ Internal Medicine, University of Ioannina, Greece, Department of Internal Medicine, Medical School, University of loannina, Ioannina, Greece, Ioannina, Greece; ${ }^{2}$ Rheumatology Clinic, University of loannina, loannina, Greece, Department of Internal Medicine, Medical School, University of loannina, Ioannina, Greece; ${ }^{3}$ Radiology, University of loannina, Greece, Department of Radiology, Medical School, University of loannina, loannina, Greece

Background: Systemic inflammation is an additional and independent predictor of cardiovascular disease (CVD) in rheumatoid arthritis (RA). It is worth mentioning that lipid levels, blood pressure and other major risk factors of CVD constitute a wide field of investigation in case of treat ment with biological disease-modifying anti-rheumatic drugs (DMARDs).

Objectives: The aim of this study is to assess the impact of biological agents on markers of CVD risk in patients with RA.

Methods: This is a prospective, observational study which included biologic-naïve RA patients treated with synthetic DMARDs, who had a negative history of CVD. Thirty-one patients and 31 healthy matched-controls (for gender, age and smoking) were compared for total cholesterol (TC) high-density lipoprotein cholesterol (HDL-c), low-density lipoprotein cholesterol (LDL-C), triglycerides (TGs), Apolipoprotein A1 (ApoA1), Apolipoprotein $B(A p o B)$ and Lipoprotein $A(L p A)$. Additionally, an ultrasonographic measurement of intima-media thickness (IMT) of carotids was performed by an experienced sonographer to all patients in order to detect the presence of atherosclerosis at baseline. Furthermore, in a subgroup of 19 of these 31 RA patients, the parameters we previously reported (except for IMT) were compared between baseline and a 3-month follow up. We also compared disease activity indexes [disease activity score (DAS28) erythrocyte sedimentation rate (ESR), C-reactive protein (CRP)] at these predefined time-points.

Results: As regards the demographic characteristics of 31 RA patients, the mean (SD) age was 54.7 (14.05) years, disease duration was 4.5 (1.3) years, there were $11(35.5 \%)$ men and 20 (64.5\%) women and 6 $(31.6 \%)$ smokers. As far as the immunological profile of patients is considered, 17 (54.8\%) were $\mathrm{RF}(+)$ and 8 (25.8\%) ACPA(+). The comparison of the parameters between RA patients and matched-controls revealed an increased IMT in RA patients [0.9 (0.17) vs $0.6 \quad(0.13) \mathrm{mm} ; \quad \mathrm{p}<0.001]$ while the other parameters involving the lipid profile did not differ among the two groups.

In the subgroup of 19 patients, there was a significant increase in mean (SD) HDL-C and ApoA1 levels from baseline to 3-month follow-up [55.3 (15.44) vs $61.68(15.3)$ and $163.16(28.89)$ vs $173.11(29.65)$ respectively $\mathrm{p}<0.05)$ ]. There was also a reduction in mean systolic blood pressure $[137.89(14.36)$ vs $130.53(12.68) ; \mathrm{p}<0.05)]$, diastolic blood pressure [81.63 (6.8) vs 77.63(6.09); $\mathrm{p}<0.05)]$, ESR $[25.53(18.57)$ vs 19.84(16.44); $\mathrm{p}<0.05)]$ and DAS28 score $[3.41(1.14)$ vs $2.62(1.12) ; p<0.05)]$. No 